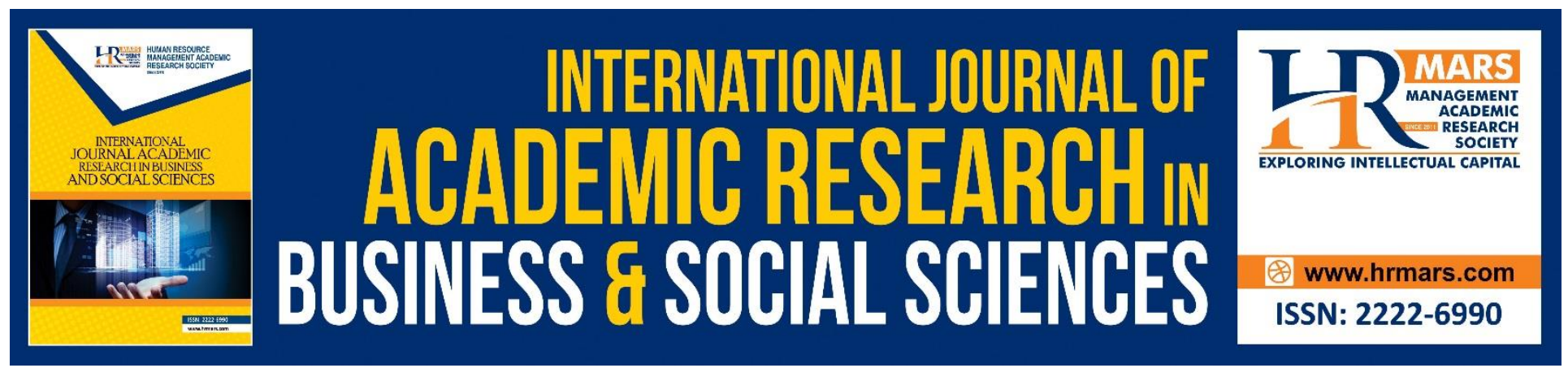

\title{
Factors Influencing Career Success Among Women Managers: A Research Framework
}

Venisa Ratha Krishnan, Siti Noormi Alias, Khairuddin Idris

To Link this Article: http://dx.doi.org/10.6007/IJARBSS/v10-i9/7826

DOI:10.6007/IJARBSS/v10-i9/7826

Received: 14 June 2020, Revised: 19 July 2020, Accepted: 14 August 2020

Published Online: 28 September 2020

In-Text Citation: (Krishnan, Alias, \& Idris, 2020)

To Cite this Article: Krishnan, V. R., Alias, S. N., \& Idris, K. (2020). Factors Influencing Career Success Among Women Managers: A Research Framework. International Journal of Academic Research in Business and Social Sciences. 10(9), 470-484.

Copyright: (C) 2020 The Author(s)

Published by Human Resource Management Academic Research Society (www.hrmars.com)

This article is published under the Creative Commons Attribution (CC BY 4.0) license. Anyone may reproduce, distribute, translate and create derivative works of this article (for both commercial and non-commercial purposes), subject to full attribution to the original publication and authors. The full terms of this license may be seen

at: http://creativecommons.org/licences/by/4.0/legalcode

\section{Vol. 10, No. 9, 2020, Pg. 470 - 484}

Full Terms \& Conditions of access and use can be found at http://hrmars.com/index.php/pages/detail/publication-ethics 


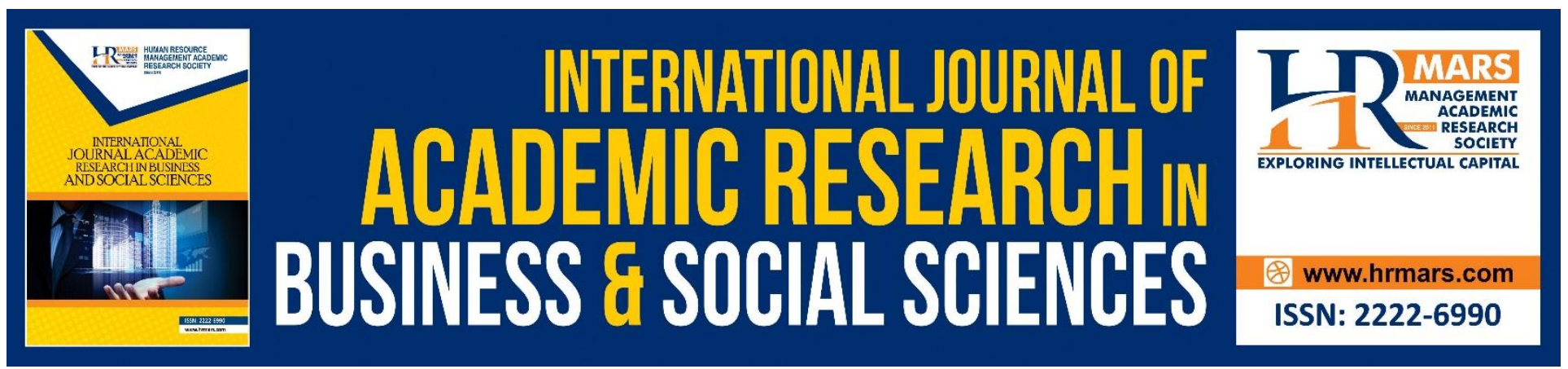

\title{
Factors Influencing Career Success Among Women Managers: A Research Framework
}

\author{
Venisa Ratha Krishnan, Siti Noormi Alias, Khairuddin Idris \\ Department of Professional Development and Continuing Education, Universiti Putra Malaysia, \\ Selangor, Malaysia. \\ E-mail:venisa9330@gmail.com, noormiey@gmail.com/ sitinoormi@upm.edu.my, \\ kidin@upm.edu.my
}

\begin{abstract}
The purpose of this paper is to reviews recent literature on women at work, through an analysis of existing literature, in order to identify factors that contribute to the success of women managers in their careers. This study is based on an extensive review of past research on career success. To conduct the literature review, keywords such as career success, job flexibility, family culture, networking and career success among women managers. Besides that, the ideas of this study arranged according to the year which are from 1988-2019. The paper offers a number of propositions which explains the proposed model of career success among women managers. Future research is recommended to test and validate the framework to provide empirical evidence. The paper yields a new approach in theorizing career success among women managers by integrating the social capital theory and social cognitive career theory. Upon model validation, the paper can offer practical interventions for human resource development (HRD) managers to help women managers in managing the career success.
\end{abstract}

Keywords: Career Success, Job Flexibility, Family Culture, Network Support and Mentoring.

\section{Introduction}

Women workforce has increase remarkably as compared to male workforce across the globe. According to International Labour Organization (2020) female labour force participation rate worldwide is $\mathbf{5 2 . 4 7}$ per cent in 2019. This shows that women are also equally entering into the working world as men. Even though the graph portraying number of women participations in workforce keep moving upwardly, however their representation at management level are still low in the organizations. This phenomenon gained a lot of attention and given rise to public discussion in Malaysia and worldwide (Eurostat, 2018). Statistics shows that corporate hierarchy is inversely related to number of women workforce at the top management (Eurostat, 2018). Although progress has been made in many employment areas (e.g. family friendly policies and incentives), number of women remains significantly low at the top management (Chondland \& Murphy, 2018). 
INTERNATIONAL JOURNAL OF ACADEMIC RESEARCH IN BUSINESS AND SOCIAL SCIENCES Vol. 10, No. 9, 2020, E-ISSN: 2222-6990 @ 2020 HRMARS

The "glass ceiling" concept has been used to explain the female's underrepresentation in managerial positions. The concept describes the invisible barrier of prejudice and discrimination that women face as they approach the top of the corporate hierarchy. There are several factors which help women to break through the glass ceiling and achieve success in their career. Career success of women in higher management position are generally associated with good governance, effective leadership, integrity, more equitable societies, and strengthened economies (Kymlicka \& RubioMartin, 2018).

Career success was described as the successful outcome or attainment individual has assembled as a consequence of involvement in work, including happiness, psychological health, and longevity (Pan \& Zhou, 2013). Interpretation of career success are divided into two dimension. Firstly, is the objective career success, it is in an observable indication such as salary and number of promotions. Secondly is the subjective career success, the unobservable indication derived from individual intrinsic and extrinsic satisfaction as a result of career success, including career advancement, pay, and developmental chance. Studies on career success found that it is important to consider both objective and subjective evaluation of career success as the two dimensions of success are judged differently by individual pursuing career ( $\mathrm{Ng}$, Eby, Sorensen \& Feldman, 2005).

\section{Knowledge Gap}

The increasing number of women entering into the professional occupations which traditionally dominated by men have triggered the growing interest in the study of women's career success. Mostly women are involved in the sectors such as health, education and personnel service sector (Omar \& Davidson, 2001). Due to better academic qualifications, some of them had joined professional careers and management position in both public and private sector organizations. However, researchers have found that there is still existing gap between men and women's career success that cause many women were unable to reach higher management position (Gonzales, Forcen \& Sanchez, 2019) due to the perception of men are more capable and effective to be in the decision making positions (Pravitha \& Indrajith, 2017). Traditionally, men are perceived to be chosen for high risk occupation compared to women (Pravitha \& Indrajith, 2017). Therefore, it reduces the chances for women to do such assignments.

Previous studies on women career success mostly focusing on objective gained only. For example, study by Giraud, Bernard and Trinchera (2019) on professional mentor, international experience, job-hopping, and gender with objective career success, Bagdadli and Gianecchini (2019) study on organizational career management practices and objective career success, Blickle, Schutte and Wihler (2018) study on political will, work values and objective career success. Adapa and Sheridan (2019) has stressed that study on career success must consolidate the objective and subjective success because career success of professional women is not completely an objective construct. A subjective perception of success brings about increase in the motivation and performance of women managers. Besides the clear perception of objective and subjective career success, different predictors are also assumed for objective and subjective career success. Therefore, more investigation is necessary to reveal the subjective component of career success among women.

By reviewing the previous literature, studies on career success among women managers mostly looked into glass ceiling, personal factor, organizational factor, societal factor and career success (Azeez \& Priyadarshini, 2018), career preferences, individual investment, individual skills, hard work, work life balance and career success (Rijal \& Wasti, 2018), personal strategies, 
INTERNATIONAL JOURNAL OF ACADEMIC RESEARCH IN BUSINESS AND SOCIAL SCIENCES Vol. 10, No. 9, 2020, E-ISSN: 2222-6990 @ 2020 HRMARS

organizational strategies, career experience and career success (Patwardhan, Mayya \& Joshi, 2018), gender, leadership, leadership development and career success (Lamsa \& Savela, 2019) and networking and career success (Ehido, Ibeabuchi \& Halim, 2019), however, rarely found studies that integrate all of family and organizational factors into a study. Such study is necessary to shed a light on the phenomenon and providing predictable solution to both employees and employers. Specifically, not many studies focusing on the influence of job flexibility, family culture, network support and mentoring on career success. Therefore, this study will review the potential influence of these four variables on career success.

The following part in this article explain the following subtopics: definitions of career success, relevant theories of career success, theoretical framework, methodology attempted in this study and factors of career success. The final part of this paper explains the implications to HRD and a conclusion in which a framework developed outlining the relationship between factors of career success (job flexibility, family culture, network support and mentoring).

\section{Objectives of Study}

- To determine the level of job flexibility, family culture, network support, and mentoring and career success among women managers.

- To determine the relationship between job flexibility, family culture, network support, and mentoring with career success among women managers

- To determine the influence of job flexibility, family culture, network support, and mentoring on career success among women maagers

\section{Career Success Defined}

In the career literature, career success has been defined in many varieties of ways by different scholars. Career success generally corresponds with the attainment and good result in regards to a person's job. Career success defined by Hennequin (2007) as the person's judgement of attainment in a person's involvement in the particular work. These definitions highlight results in terms of relationships and network, individual, job and organizational development.

Career success is also defined as a set of positive (objective career success) and psychological (subjective career success) consequences that derive from individual work experience (Seibert, Kraimer \& Crant, 2001). Objective career success is also defined as the higher level of material gain, employment fulfilment (Blickle et al., 2018) as well as other job and career variables (Spurk, Hirschi $\&$ Dries, 2019). Example of noticeable career success include promotions, increase in income, job position, and the degree of accomplishment

Subjective career success is defined as the individual's evaluations and experience of achieving personal meaningful career outcomes (Shockley, Ureksoy, Rodopman, Poteat \& Dullaghan, 2016). Subjective career success builds on personal appraisal of accomplishment which comprises the judgement of intrinsic and extrinsic career end-result and it is usually appraise by career accomplishment or general affect-based measures ( $\mathrm{Ng} \&$ Feldman, 2014). Subjective aspect of career success is very crucial for many women managers as their own opinion that subjective career success is more important than objective aspect of career success. Subjective dimension of career success is an important aspect of career since it offers a person with a conducive appraisal of their job in respect to the upcoming vision and previous attainment. Subjective career success determines career 
INTERNATIONAL JOURNAL OF ACADEMIC RESEARCH IN BUSINESS AND SOCIAL SCIENCES

Vol. 10, No. 9, 2020, E-ISSN: 2222-6990 @ 2020 HRMARS

fulfilment, work achievement, promotion contentment and recognized career success. Career expectation and job security are positively related to subjective career success.

\section{Theorizing Career Success}

The phenomenon of career success among women managers can be explained by two theories, viz., Social Cognitive Career Theory and Social Capital Theory. These theories are crucial in analyzing the relationship of independent variables which are the organizational factor (job flexibility, network support, mentoring) and family factor (family culture) with career success. (Table 1). Detail explanation about these theories in relation to career success discussed in the sections that follow.

\section{a. Social Cognitive Career Theory}

Lent, Brown and Hackett (1994) developed Social Cognitive Career Theory (SCCT) to describe three forms of career development which are the construction and description of career-relevant interests, the choosing of career choice options, and performance and endurance in employment objectives. This theory will explain the relationships between job flexibility and family culture with career success. The originator of SCCT targeted their consideration on the three social cognitive system that they expected significant to career development. Lent et al. (1994) affirms the interdependence among self-efficacy beliefs, outcome expectations and goal mechanism and another person (eg. gender), contextual affordance (eg. support system) and learning experience.

According to Chiesa, Massei and Gugiemi (2016), self-efficacy firmly associated to one's awareness close to self-capability that aid to restraint the anxiety in a specific condition. Besides that, outcome expectation refers to a person's opinion on the feasibility of a specific end result refers to outcome expectation (Sharf, 2006). People usually make choice regarding the action they are engaged in and their attempt and determination of certain activity, consideration needed for a specific outcome as well as their self-efficacy judgement. For example, individuals are more anticipated to participate in an activity which they see their participation as key to valued favourable outcome. Moreover, goals help to organized an individual's behaviour to guide actions which perceived as self-motivating because an individual feel satisfied when goals are accomplished. Individual usually established goals which are persistent with their views regarding their own potential and end result that they expect to achieve in seeking a particular approach of action. As explained by Sharf (2006), self-efficacy, outcome expectation and goals are all interconnected and these influence each other in diverse ways.

Furthermore, according to SCCT, contextual affordance refers to environmental influences. Vondracek, Lerner and Schulenberg's (1986, p. 38) described contextual affordance as "the idea that environments offer, provide, and /or furnished something to the individual as long as the individual can perceive 'it' as such" According to Lent (2013), contextual affordance includes distal and proximal influences. Distal influence is the element that either confine or aid the progress of self-efficacy and outcome expectations (e.g. gender-role socializations, deplete learning environment), while proximal influence affects the implementations of choice (e.g. dread about moving, financial assistance). In this study, job flexibility and family culture are more to distal influence. This is because SCCT posits that certain features (e.g. job flexibility) of the opportunity structure influence people's ability to translate their interest into career goals and goals into action. In an organization, the important post of top management in terms of their relationship to division of executive will affect the organizational environment (e.g., culture, norm, values, expectations), which in turn affect employees' behaviour. 
INTERNATIONAL JOURNAL OF ACADEMIC RESEARCH IN BUSINESS AND SOCIAL SCIENCES Vol. 10, No. 9, 2020, E-ISSN: 2222-6990 @ 2020 HRMARS

Organizations need to focus on their important resources, which is their employees, particularly women. If employees perceived their company concern about their wellbeing, they will be more committed and engaged with their work.

Moreover, SCCT was developed based on how people, their action and surrounding correlate to one another. Self-efficacy, outcome expectations and personal goals which effect one's career decision are highlighted in the theory. SCCT indicated that "certain conditions may directly affect people's choice of implementation possibilities" (Lent, 2005, p.110). Example by Lent states that "in certain cultures, individuals may differ their career decisions to others in the family, even when others' preferred career path is not all that interesting to the individual" (p.110). SCCT basically proposed that sometimes a person's career option is connected to their interest due to the situation that may need a settlement based on own interest. This concept can be use in the career growth of women managers as their success in career are mostly associated with family factors and cultures with less on their personal interest.

\section{b. Social Capital Theory}

Researchers administer Social Capital Theory (SCT) as primary theory for career success (Nikitkov \& Sainty, 2014; Seibert, Crant \& Kraimer, 2001). SCT according to Lin (2001) posits that contribution of assets such as trust, norms, and network essential in collective relationship with expected acknowledgement. This theory will explain the relationships between network support and mentoring with career success. Friesen (2011) states that capital exists in forms other than monetary or tangible, liquid assets.

Moreover, Metz and Tharenou (2016) emphasized that the significant of social capital is more important especially for women and minorities' career success. Research shows that women can lack authenticity or acceptance in the workplace, causing them to be an outsider with less amount of social capital (e.g., Lutter, 2015). Young men also tend to have authenticity issues but they have been shown to gain legitimacy with promotions and experience, while women often continue to have acceptance issues throughout their career (Lutter, 2015). Women may be able to attach themselves to a strong, interconnected group or a powerful mentor and borrow the social capital necessary to success in their career.

In accordance, SCT can also contributes to our understanding on mentoring association. Even though there is a great amount of literature on social capital, it is solely and cohesive. To understand how social capital is deploying in mentoring association, the notion of capitalization is needed to be paid attention. SCT builds on the idea of (1) network properties (2) relevant resources (3) access to resources. For the network properties, according to Chow and Chan (2008) social capital theory affirms that approach to fixed assets build upon network capacity, depth and ranking. This is because, if the relationship is with people who have more acquire influence and authorization at greater bureaucratic level, it is seen that social capital is more valuable (Seibert, Kraimer \& Liden, 2001). Besides that, for the relevant resources, because assets ingrained in network, social capital focuses on knowledge, aid and expert expertise provided through mentoring association. In a mentoring relationship it is crucial to communicate professional norms which include assumptions about time spend in the workplace, access to envy files, sharpening of legal talents under close administration and recognition for unexpressed outlook about bureaucratic dedication. Moreover, for access to resources, even though social capital is an asset that may be readily commerce for a wider display of valuable end result by both mentee and mentor, it must be assemble and managed well in order to 
INTERNATIONAL JOURNAL OF ACADEMIC RESEARCH IN BUSINESS AND SOCIAL SCIENCES Vol. 10, No. 9, 2020, E-ISSN: 2222-6990 (C) 2020 HRMARS

be utilize. Individual are pledge to strongly mobilized their total collective assets of capital and change it to significant result which include payment, advancement in higher position or professional status.

\section{Theoretical Framework}

The Social Cognitive Career Theory of Lent et al. (1994) was used as the theoretical framework for this study (see Fig. 1).

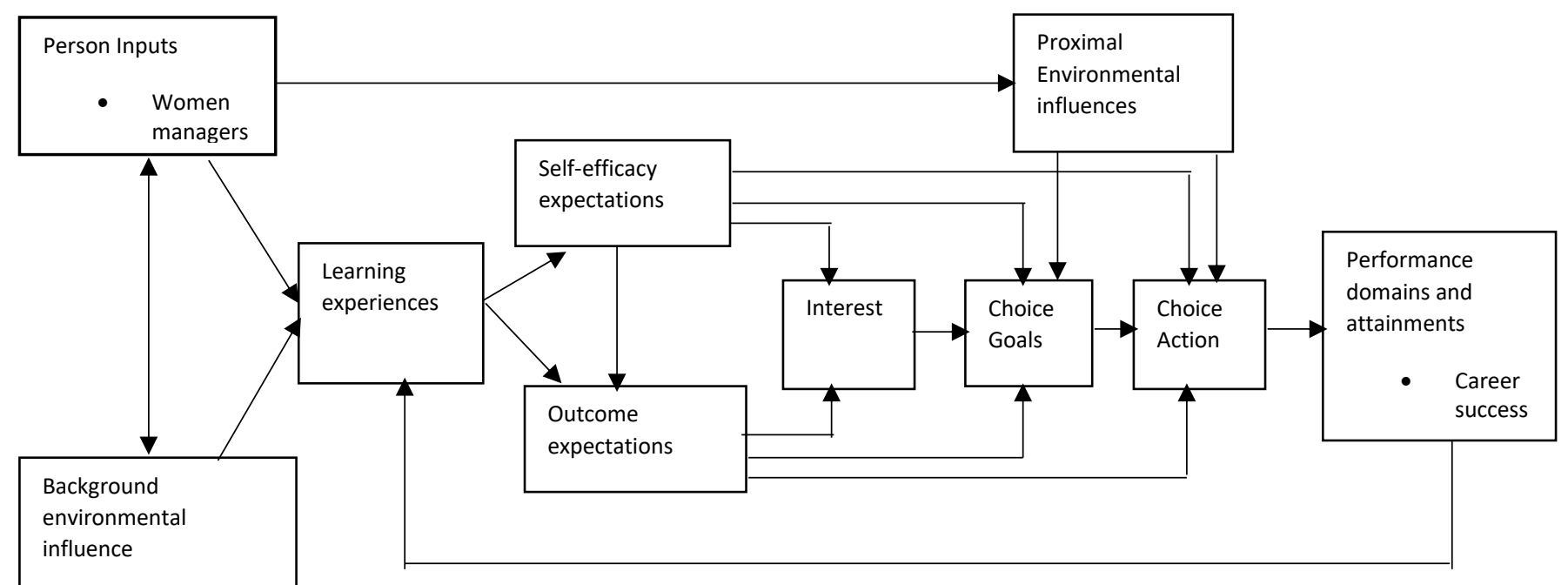

- Job

Flexibility

- Family

Culture

- Network

Support

- $\quad$ Mentoring

Fig. 1. Theoretical Framework

\section{Method}

This paper is based on extensive reviews of previous research on career success, including local and global studies accessible through online databases such as Google Scholar, Education Resources Information Center (Eric), Scopus, Science Direct, Jstor and Directory of Open Access Journal, Semantic Scholar. The method of extracting the appropriate literature began with the choosing of precise keywords as suggested by Cronin, Ryan and Coughlan (2008). Few keywords were discovered by researcher for example career success, job flexibility, family culture, network support and mentoring to search the literature researching on women managers career success. Various electronic databases were used to seek for supporting evidence and resources that encompasses journal articles, books and institutional reports by multidimensional organizations. Total 120 items were obtained from the past studies used in the analysis was based on both quantitative and qualitative analysis, of which about 10 percent was from Asia and the rest from Western countries from 1988 to 2019. From the 120 articles sourced, approximately about 90 articles was conducted based on women managers and the remaining was conducted on general women employees in which 105 articles was empirically tested including both the private and public sector organizations. Approximately about 115 articles out of 120 articles are from journals and the remaining was from institutional reports and books. From the 120 articles, 20 articles were from job flexibility and career success among women managers, 18 articles were from family culture and career success among 
INTERNATIONAL JOURNAL OF ACADEMIC RESEARCH IN BUSINESS AND SOCIAL SCIENCES Vol. 10, No. 9, 2020, E-ISSN: 2222-6990 @ 2020 HRMARS

women managers, 25 articles were from network support and career success among women managers, 40 articles were from mentoring and career success among women managers and the remaining was on articles from career success among women managers. However, 80 percent of them were use in this analysis because these articles are correlated with the variables of career success among women managers.

\begin{tabular}{|l|l|l|}
\hline Regions & Sources & $\begin{array}{l}\text { Number } \\
\text { of Items }\end{array}$ \\
\hline $\begin{array}{l}\text { Western } \\
\text { (USA } \\
\text { and UK) }\end{array}$ & $\begin{array}{l}\text { Group \& Organization Management, Journal } \\
\text { of Applied Psychology, Journal of Vocational } \\
\text { Behaviour, Personnel Psychology, Career } \\
\text { Development International Journal, An } \\
\text { International Journal, Journal of Business } \\
\text { Ethics, Women in Management Review, } \\
\text { Leadership and Organization Development, } \\
\text { International Journal of Human Resource } \\
\text { Management. }\end{array}$ & \\
\hline $\begin{array}{l}\text { Asia } \\
\text { (China, } \\
\text { India } \\
\text { and } \\
\text { Malaysi } \\
\text { a) }\end{array}$ & $\begin{array}{l}\text { The International Journal of Human Resource } \\
\text { Management, Journal of European Industrial } \\
\text { Studies, Pertanika Journal of Social Science } \\
\text { and Humanities. }\end{array}$ & 12 \\
\hline
\end{tabular}

Furthermore, the variables covered from the 120 articles were mentoring, male-dominated organizational culture, network support, training and development, personal factors, organizational factors, flexible work arrangements, gender, human capital and family factors. Most of these studies are conducted among women employees in educational field, engineering, manufacturing, private sector organizations and banking sectors in from various countries such as Turkey, Arab Saudi, Africa, India, China, USA, UK and Malaysia. In addition to this, the theories used in these articles are Social Cognitive Career Theory, Human Capital, Social Capital Theory, Social Learning Theory and Social Influence Theory.

\section{Findings}

The research framework is design based on past studies on the factors influencing career success among women managers. This framework is supported by the SCCT and SCT. The framework of this study is shown in Fig. 2. The framework of this study indicates that career success factors (job flexibility, family culture, network support and mentoring) affect career success directly. 
INTERNATIONAL JOURNAL OF ACADEMIC RESEARCH IN BUSINESS AND SOCIAL SCIENCES Vol. 10, No. 9, 2020, E-ISSN: 2222-6990 @ 2020 HRMARS

Independent Variables Dependent Variable

Factors Influencing Career Success

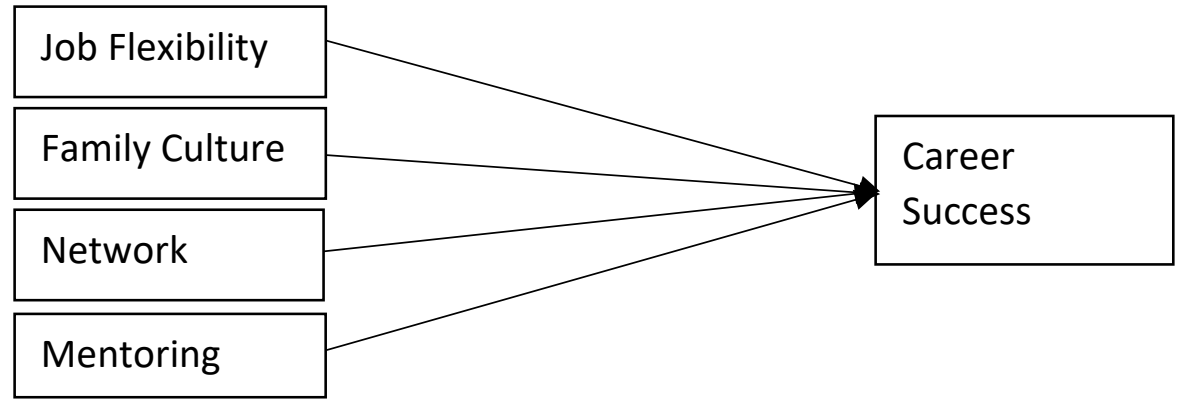

Fig. 2. Research Framework

\section{Factors associated to career success}

\section{a. Job Flexibility}

Job flexibility is defined as the flexibility one has on the duration of work, location and amount of work. Job flexibility can be described as authority given to employees to decide on when and where to accomplish their work. According to Edward, Clifton and Kruse (1996) it is different from some work arrangements that refer to employer's ability to change work schedule and lay off employees. Job flexibility is designed to help employees especially women to balance their work and non-work responsibilities. Parents' application of job flexibility beyond part time, for example adjustable working hours and telecommuting however may help the employer to signal that the workers are striving to merge their job while taking care of their children and elderly without lessening the period of time they occupy at workplace. Job flexibility benefits career-orientated women to balance between work and family and they will eventually stay in their profession, even when their work are critical. therefore, this will eventually cause more women advancing into the higher management position. Lent, Brown and Hackett (1994) in the theory of social cognitive career theory states that job flexibility enables the employers to have good insight on the employees whereby this may help them to increase the opportunities for promotion to a higher job position in an organization. Furthermore, the utilization of job flexibility can influence intrinsic career success.

Study by Leslie, Manchester, Park, and Mehng (2012) addressed that job flexibility results in work productivity among women employees. This result is empirically confirmed by Lyness and Judiesch (2014) study which showed that job flexibility was positively significant with career success among Malaysian women managers. The study is consistent with the previous research by Mcnall, Nicklin and Masuda (2010) on job flexibility who found that flexi time and compressed work week help employees to experience higher job satisfaction and career success. Therefore, based on the SCCT theory and supported by previous studies, this study hypothesizes that:

$P 1$. There is a significant and positive relationship between job flexibility and career success among women managers.

\section{b. Family Culture}

According to Mordi, Simpson, Singh and Okafor (2010) and Piacentini (2013), women in management level have difficulties to disclose themselves to the employment world due to the cultural values. In the context of women career success, family culture has been examined carefully (Lirio, Lituchy, Monserrat, Olivas- Lijan, Duffy, Fox, Punnett \& Santos, 2007), particularly in relational to marital 
status and day-care provider. Many studies have showed that combining both family and career domain may obstruct a women's career success. According to Powell and Graves (2003) research have showed that in the West, women managers struggle to build choices, such as staying unmarried or having no children in relation to their male working colleagues, in which most of them are married with children. This is because family culture affected negatively on women career success due to the judgement that being a wife and mother can promote to interruption in their career and they might progress slowly especially for those who women at the higher management level. The study is empirically supported by Linge (2015) found that family responsibilities and have a significant relationship with the women managers career success. On the other hand, other culture outside the Western countries, that highlighted the significance of family network, have states that mothership is not an obstacle to women's employment (Lirio et al., 2007). Evidence had shown that women who obtain help from their family members face less strain and greater career growth than women who do not get help from their family members because the assistance from family members have affect positively on women's career success for better performance at work by increasing their positive feelings (Baral \& Bhargava, 2011).

Based on these findings and theory of SCCT, this study proposed that family culture have positive influence on women's career success. Therefore, the second hypothesis is that:

P2. There is significant and positive relationship between family culture and career success among women managers.

\section{c. Network Support}

According to Wolff and Moser (2006) network support is defined by action that are aimed at establishing, sustaining and utilizing informal relationship that have the possibility benefits to aid activities of individual that related to work by freely getting access to assets and magnifying accepted advantages. Network support describes typically how regularly people exhibit networking attitude (e.g., discussing business issues outside of employment time or using communication to get private guidance.

Ferris, Treadway, Kolodinsky, Hochwarter, Kacmar, Douglas and Frink (2005) found that network support has affect career success due to the accommodation of high networking people tend to control bond, contact and social capital. The study is empirically confirmed by Huang (2016) which stated that continuing such network for example, maintaining contacts and participating in experienced activities was positively significant to career success such as promotion. Moreover, social network is determined as mechanism to obtain new knowledge such as guidance of information and route for socialization. According to Arokiasamy, Ismail, Ahmad and Othman (2011) discover networking to be positively related to career progress of female managers in Malaysia in which the career progress result in promotion, increment in salary, goal accomplishment and learning. Thereby, this indicated that network support is an essential mechanism to improve the career progression among employees (Seibert, Crant \& Kraimer, 2001). Therefore, network support can enhance career success and this brings to wider network of connection with more chances to differentiate one's success with another individual. Supported by theory of social capital theory, the third hypothesis is that:

P3. There is significant and positive relationship between network support and career success among women managers 
INTERNATIONAL JOURNAL OF ACADEMIC RESEARCH IN BUSINESS AND SOCIAL SCIENCES Vol. 10, No. 9, 2020, E-ISSN: 2222-6990 @ 2020 HRMARS

\section{d. Mentoring}

According to Alleman and Clarke (2002) mentoring is explained as the association between two people where a person with higher position, experienced or skilful leaders, guide and assists another individual to progress and grow one's both professional and personal life. Throughout the literature, mentoring in the organization helps women managers for advancement in their career. Mentors plays and important role in female managers' career success as they assist them to develop sense of individuality, professional confidence, minimize discrimination, assist female managers to get information which are accessible to men, provide decision-making authority within the organization and aid their career success.

Research on career success shows that mentoring is a crucial factor to explain the career success of women managers. Mentoring has an interactive and positive association between the more experienced person and less experience person which in turn prompt to career success (Schmidt \& Faber, 2016). This statement is supported by Parsa, Parsa \& Parsa (2016) who states that mentoring is positively significant with women managers' career advancement. Therefore, according to Parsa et al. (2016) mentoring can be used as a medium for career success. Furthermore, mentoring was significantly related to career success of women (Abalkhail \& Allan, 2015). Based on theory of social capital theory and the above empirical support, this study hypothesizes that,

P4. There is a significant and positive relationship between mentoring and career success among women managers

\section{Implications to Human Resource Development (HRD)}

Career success has been a vital goal among women in the organization to reach to managerial position. Organizations need to put effort in addressing the matter to increase the number of women to top managements. As a results, it helps to promote an appreciative surrounding to fascinate and maintain more women managers in the Malaysian employment. Through the findings of this study, management can generate a conducive environment for women employees to maintain in the organizations such as providing more flexibility work arrangements for women. Management should consider flexi hours in which employees are able to adjust the working time accordingly. Flexible work arrangement helps women employees as it benefit them to increase their performance at workplace and personal life effectively. Through the findings of this study, organizations can create familyfriendly policies such as providing affordable and assessable childcare centres. Therefore, women managers are able to focus on work knowing that their children are in safe hands. This will eventually benefit the employers of the organizations as this flexibility seen to improve employees work commitment and performance. Hence, the organizations productivity will also be improved.

Network support is also crucial component of the operation of growth and release human potentials and proficiency to attain personal and professional performance. Network may include those inside and outside organization. Organization may provide career counselling service to employees. At the same time, organizations also may provide opportunities for networking by sending out their employees for local and international assignments. This is because career counselling service helps employees to discover convenient to associate with distinct forms of mentors and advisors, gain their clarity with top management and progress their field of proficiency as well as enhance their soft skills and this will eventually help in their career progression.

Besides that, to assess the effectiveness of the present mentoring program, organization can utilize the quantitative result of this study on the advantage and challenges of the mentoring. This 
INTERNATIONAL JOURNAL OF ACADEMIC RESEARCH IN BUSINESS AND SOCIAL SCIENCES Vol. 10, No. 9, 2020, E-ISSN: 2222-6990 @ 2020 HRMARS

measurable study could provide a greater understanding on the mentoring association and action influencing the career success of potentiality women managers. Furthermore, with the implementation of the mentoring program, women managers can sharpen their fundamental skill to be promoted to higher position before the retirement of the present managers.

\section{Conclusion and Recommendations for Future Research}

More empirical studies should be conducted to study women career success for the reason that differences of nature of men and women, physically, mentally, psychologically as well as different perception based on religious and cultural inclination. These factors must be revealed because this knowledge would be beneficial to the organization in helping their women managers such as provide benefits, training and motivations. The present model proposes that job flexibility, family culture, network support and mentoring as factors of career success among women managers in private sector organizations.

This study present theoretical support for the four factors as antecedents of career success. Therefore, researcher propose that future research to be carried out empirically examine and justify the scheme and the relationship between the factors and career success in the model. Therefore, the empirical proof that could be acquire from this model may add to the existing literature on career success among women managers. This suggests that future research should examine in more detail the strategies to promote more job flexibility, family culture, network support, mentoring and career success among women managers.

\section{Research Contribution}

Theoretically, this study contributes more wide perspective regarding the existing theory of women managers career success by integrating two categories of factors; family factor (family culture) and organizational factor (job flexibility, network support, mentoring) in understanding women managers career success. This study provides additional information about factors related to women manager's career success through the use of Social Cognitive Career theory (SCCT). This study also contributes additional factors such as job flexibility and family culture to the existing SCCT. Thus, explaining this factors may provide a better understanding for further studies. Moreover, this study also uses Social Capital Theory to explain the relationship between two factors which are the network support and mentoring with career success among women managers. Looking into the Human Resource Development (HRD) perspective, this study would be able to provide additional insight to the relationship between factors influencing career success among women managers.

Looking into the practical point of view, this study could provide better information for decision making to organization and HRD practitioner, regarding policies and practices of organizations that are supportive to the nature and needs of women's career. Special training and intervention programs for women managers could possibly design based on the result of this study. Appropriate policies that are supportive to the need of women managers could also be based on the findings of this study. Hence, it provides a useful guidance for the government in general and to HR practitioner in each private sector organization to develop a more comprehensive action plan for the career development of women managers in the private sector organizations in meeting the national target of 30 percent of women in decision making position (Malaysia, 2010). 
INTERNATIONAL JOURNAL OF ACADEMIC RESEARCH IN BUSINESS AND SOCIAL SCIENCES Vol. 10, No. 9, 2020, E-ISSN: 2222-6990 @ 2020 HRMARS

\section{References}

Adapa, S., \& Sheridan, A. (2019). A case of multiple oppressions: women's career opportunities in Malaysian SME accounting firm. The International Journal of Human Resource Management. doi:10.1080/09585192.2019.1583269

Abalkhail, J. M., \& Allan, B. (2015). Women's career advancement: Mentoring and networking in Saudi Arabia and the UK. Human Resource Development International, 18(2), 153-168.

Alleman, E., \& Clarke, D. L. (2002). Manual for the Alleman Mentoring Questionnaire

Arokiasamy, L., Ismail, M., Ahmad, A., \& Othman, J. (2011). Predictors of academics' career advancement at Malaysian private universities. Journal of European Industrial Training, 35(6), 589-605.

Azeez, P. V. N., \& Priyadarshini, R. G. (2018). Glass ceiling factors affecting women career advancement in IT industry in India. IOP Conference Series Materials Science and Engineering, 390(1).

Bagdadli, S., \& Gianecchini, M. (2019). Organizational career management practices and objective career success: A systematic review and framework. Human Resource Management Review, 29(3), 353-370.

Baral, R., \& Bhargava, S. (2011). Predictors of work-family enrichment: moderating effect of core self-evaluations. Journal of Indian Business Research, 3(4), 220-243.

Blickle, G., Schutte, N., \& Wihler, A. (2018). Political will, work values, and objective career success: A novel approach-the trait- reputation identity model. Journal of Vocational Behaviour, 107(1), 42-56.

Chiesa, R., Massei, F., \& Guglielmi, D. (2016). Career decision-making self-efficacy changes in Italian high school students. Journal of Counseling \& Development, 94(1), 210- 224. doi:10.1002/jcad.12077

Chondland, D., \& Murphy, W. (2018). Propelling diverse leaders to the top: A developmental network approach. Human Resource Management, 57(1), 111-126.

Cronin, P., Ryan, F., \& Coughlan, M. (2008). Undertaking a literature review: A step-by-step approach. British Journal of Nursing, 17(1), 38-43.

Edward III, M. S., Clifton, T. J., \& Kruse, D. (1996). Flexible work hours and productivity: Some evidence from the pharmaceutical industry. Industrial Relations, 35(1), 123-139.

Ehido, A., Ibeabuchi, C., \& Halim, B. A. (2019). Networking and women academics' career success in the Malaysian Research Universities. International Journal of Academic Research in Accounting Finance and Management Sciences, 9(12), 940-960.

Eurostat. (2018). Positions held by women in senior management positions (source: EIGE). Retrieved 4 February 2019, from https://ec.europa.eu/eurostat/tgm/table.do?tab=table\&init=1\&language=en \&pcode=sdg _05_60\&plugin $=1$

Ferris, G. R., Treadway, D. C., Kolodinsky, R. W., Hochwarter, W. A., Kacmar, C. J., Douglas, C., \& Frink, D. D. (2005). Development and validation of the political skill inventory. Journal of Management, 31(1), 126-152.

Friesen, M. R. (2011). Immigrant's integration and career development in the professional engineering workplace in the context of social and cultural capital. Engineering studies, 3(2), 79-100. 
INTERNATIONAL JOURNAL OF ACADEMIC RESEARCH IN BUSINESS AND SOCIAL SCIENCES

Vol. 10, No. 9, 2020, E-ISSN: 2222-6990 @ 2020 HRMARS

Giraud, L., Bernard, A., \& Trinchera, L. (2019). Early career values and individual factors of objective career success. Career Development International, 24(4), 350-382.

Gonzales, J. G., Forcen, P., \& Sanchez, M. J. (2019). Men and women differ in their perception of gender bias in research institutions. PLOS ONE, 14(12). doi:10.1371/journal.pone.0225763

Hennequin, E. (2007). What 'career success' means to blue-collar workers. Career Development International, 12(6), 565-581.

International Labour Organization. (2020). Labour force female survey report 2020.

Kymlicka, W., \& Ruth, R. M. (2018). The Participatory Turn in Gender Equality and its Relevance. In Kymlicka, W., \& Ruth, R. M (Eds.), Gender Parity and Multicultural Feminism: Towards a New Synthesis, (pp. 1-45). Oxford: Oxford University Press

Lämsä, A. M., \& Savela, T. (2019). The effects of leadership development on women's career success. International Journal of Human Resources Development and Management, 19 (1), 21-36. doi:10.1504/IJHRDM.2019.097055

Lent, R. W., Brown, S. D., \& Hackett, G. (1994). Toward a unifying social cognitive theory of career and academic interest, choice, and performance. Journal of Vocational Behavior, 45(1), 79122. doi: 10.1006/jvbe.1994.1027

Lent, R. W., Singley, D., Sheu, H.-B., Gainor, K., Brenner, B. R., Treistman, D., \& Ades, L. (2005). Social cognitive predictors of domain and life satisfaction: Exploring the theoretical precursors of subjective wellbeing. Journal of Counseling Psychology, 52(1), 429 - 442. doi:10.1037/ 0022- 0167.52.3.429

Lent, R. W. (2013). Social cognitive career theory. In S. D. Brown \& R. W. Lent (Eds.), Career development and counselling: Putting theory and research to work (2nd ed., pp. 115-146). Hoboken, NJ: Wiley.

Leslie, L. M., Manchester, C. F., Park, T.-Y., \& Mehng, S. A. (2012). Flexible work practices: A source of career premiums or penalties? Academy of Management Journal, 55(6), 1407-1428

Lin, N. (2001). Social Capital: A Theory of Social Structure and Action. Cambridge University Press; NY, USA

Linge, T. K. (2015). Extrinsic factors that affect employee job satisfaction in faith based organizations. Journal of Language, Technology \& Entrepreneurship in Africa, 6(1), 72-81

Lirio, P., Lituchy, T. R., Monserrat, S. I., Olivas-Lijan, M. R., Duffy, J. A., Fox, S., Gregory, A., Punnett, B. J. and Santos, N. (2007). Exploring career- life success and family social support of successful women in Canada, Argentina and Mexico. Career Development International,12(1), 28-50. doi: 10.1108/13620430710724811

Lutter, M. (2015). Do women suffer from network closure? The moderating effect of social capital on gender inequality in a project-based labor market, 1929 to 2010. American Sociological Review, 80(2), 329-358. doi:10.1177/0003122414568788

Lyness, K. S., \& Judiesch, M. K. (2014). Gender egalitarianism and work-life balance for managers: Multisource perspectives in 36 countries. Applied Psychology: An International Review, 63(1), 96-129.

McNall, L. A., Masuda, A. D., \& Nicklin, J. M. (2010). Flexible work arrangements and job satisfaction/turnover intentions: The mediating role of work-to family enrichment. Journal of Psychology, Interdisciplinary \& Applied, 144(1), 1-21. 
INTERNATIONAL JOURNAL OF ACADEMIC RESEARCH IN BUSINESS AND SOCIAL SCIENCES Vol. 10, No. 9, 2020, E-ISSN: 2222-6990 @ 2020 HRMARS

Metz, I., \& Tharenou, P. (2016). Women's career advancement the relative contribution of human and social capital. Group \& Organization Management, 26(3), 312-342.

Mordi, C., Simpson, R., Singh, S., \& Okafor, C. (2010). The role of cultural values in understanding the challenges faced by female entrepreneurs in Nigeria. Gender in Management. An International Journal, 25(1), 5-21. doi: 10.1108/17542411011019904

Ng, T. W. H., Eby, L. T., Sorensen, K. L., \& Feldman, D. C. (2005). Predictors of objective and subjective career success: a meta-analysis. Personnel Psychology, 58(1), 367-408.

Ng, T. W. H., \& Feldman, D. C. (2014). Subjective Career Success: A Meta-Analytic Review. Journal of Vocational Behavior, 85(2), 169-179.

Nikitkov, A., \& Sainty, B. (2014). The role of social media in influencing career success. International Journal of Accounting \& Information Management, 22(4),273-294. doi: 10.1108/IJAIM-022014-0009

Omar, A., \& Davidson, M. J. (2001). Women in management: a comparative cross- cultural overview. Cross Cultural Management. An International Journal, 8(1), 35-67

Pan, J., \& Zhou, W. (2013). Can success lead to happiness and happiness. Asia Pacific Journal of Human Resources, 51(1), 60- 80.

Parsa, B., Parsa, P., \& Parsa, N. (2016). Mediation effect of self-efficacy on the relationship between mentoring function and career advancement among academics in Iran. Global Journal of Health Science, 8(10), 295-306.

Piacentini, M. (2013). Women entrepreneurs in the OECD: key evidence and policy challenges. OECD Social, Employment and Migration Working Papers, 147(1). doi: 10.1787/5k43bvtkmb8v-ena

Pravitha, N. R., \& Indrajith. (2017). A study on factors influencing team effectiveness in a resort environment. International Journal of Scientific Research, 6(6).

Rijal, S., \& Wasti, S. P. (2018). Factors influencing career progression of working women in health services: A case from Kathmandu Valley in Nepal. International Journal of Healthcare Management, 11(3), 164-170.

Schmidt, E. K., \& Faber, S. T. (2016). Benefits of peer mentoring to mentors, female mentees and higher education institutions. Mentoring \& Tutoring. Partnership in Learning, 24(2), 137-157.

Seibert, S. E., Crant, J. M., \& Kraimer, M. L. (2001). What do proactive people do? A longitudinal model linking proactive personality and career success. Personnel Psychology, 54(4), 845.

Sharf, R. S. (2006). Applying career development theory to counseling. Belmont, CA:Thomson

Shockley, K. M., Ureksoy, H., Rodopman, O. B., Poteat, L. F., \& Dullaghan, T. R. (2016). Development of a new scale to measure subjective career success: A mixed-methods study. Journal of Organizational Behaviour, 37(1), 128-153

Spurk D., Hirschi A., \& Dries N. (2019). Antecedents and outcomes of objective versus subjective career success: Competing perspectives and future directions. Journal of Management, 45(1), 35-69. doi: 10.1177/0149206318786563

Vondracek, F. W., Lerner, R. M., \& Schulenberg, J. E. (1986). Career development: A life-span developmental approach. Hillsdale, NJ: Erlbaum.

Wolff, H.-G., \& Moser, K. (2006). Entwicklung und Validierung einer Networkingskala [Development and validation of a networking scale]. Diagnostica, 52(1), 161-180. doi:10.1026/00121924.52.4.161. 